\title{
Microstructural and histochemical analysis of aboveground organs of Centaurea cyanus used in herbal medicine
}

\author{
Weronika Haratym $^{1} \cdot$ Elżbieta Weryszko-Chmielewska ${ }^{1} \cdot$ Agata Konarska $^{1}$ (D)
}

Received: 10 May 2019 / Accepted: 28 August 2019 / Published online: 12 September 2019

(C) The Author(s) 2019

\begin{abstract}
Centaurea cyanus $\mathrm{L}$. is a valuable source of many different bioactive substances. It is used in herbal medicine, but the structure of its organs used as raw material and secretory tissues has been insufficiently examined. The aim of this paper was to investigate the microstructure of $C$. cyanus flowers, bracts, stems and leaves with particular emphasis on secretory structures. Moreover, the main classes of secondary metabolites present in the secretion were identified and the taxonomic value of some micromorphological and anatomical features was analysed. Histochemical, micromorphological and ultrastructural analyses of aboveground organs of $C$. cyanus were carried out using light, fluorescence, scanning and transmission electron microscopy. The analyses revealed the presence of petal papillae and a characteristic cuticular pattern on the petals, stamens and stylar hairs. There were four types of non-glandular trichomes on the bracts, leaves and stem surfaces. The epidermal cells of the bracts contained prismatic calcium oxalate crystals. Two kinds of secretory structures, i.e. glandular trichomes and ducts, were observed in the C. cyanus organs. The glandular trichomes were located on the bract and stem surfaces, and the ducts were detected in the leaves and stems. Ultrastructural analyses of the epithelium of the ducts showed the presence of strongly osmiophilic insoluble phenolic material in vacuoles as well as moderately osmiophilic insoluble lipidic material in elaioplasts and vesicles. The results of histochemical assays showed a heterogeneous nature of the duct secretion, which contained essential oil, lipids, flavonoids, tannins and terpenes containing steroids.
\end{abstract}

Keywords Micromorphology and anatomy $\cdot$ Centaurea $\cdot$ Scanning electron microscopy $\cdot$ Histochemistry and ultrastructure Secretory structures $\cdot$ Medicinal plant

\section{Introduction}

Centaurea L. is a large polymorphous genus from the tribe Cardueae (Asteraceae family). It comprises annual, biennial and perennial grassy plants occurring worldwide, especially in America, Europe, North Africa and Asia (Wagenitz and Hellwig 1996; Susanna and Garcia-Jacas 2009; Rai and Kon 2013). Only 21 species grow in Poland. They are mostly associated with Festuco-Brometea and anthropogenic communities (Mirek et al. 2002).

Handling Editor: Peter Nick

Agata Konarska

agata.konarska@up.lublin.pl

1 Department of Botany, Faculty of Horticulture and Landscape Architecture, University of Life Sciences in Lublin, Akademicka 15, 20-950 Lublin, Poland
The best-known species is Centaurea cyanus L., which originated in the Caucasus. Since ancient times, it has dispersed as a weed into crop fields, especially in wheat and canola plantations, or along field margins (Rösch 1998; Wassmuth et al. 2009; Boršic et al. 2011). This annual plant has a branched stem and a tap root system. Its lanceolate leaves are arranged alternately on the stem. Flowers appear from the first week of June to mid-August, reaching full bloom in the first week of July. The plant produces inflorescences composed of sterile peripheral deep blue ray florets and fertile tubular disc florets with an ovary containing a single ovule (Denisow 2006). The fruit is an achene (Chiru et al. 2013).

The medicinal raw material Cyani flos is used in herbal medicine (Polish Pharmacopoeia VIII 2008). The main active ingredients of cyani flos are amino acids, aromatic acids, coumarins, flavonoid derivatives, indole alkaloids, phenylcarboxylic acids, polyphenols and polysaccharides (Litvinenko and Bubenchikova 2007; Muravéva and 
Bubenchikova 2007; Pirvu et al. 2015). With its content of these substances, this plant is reported to have anti-inflammatory, antimicrobial, antipruritic, antitussive, astringent, cholagogic, diuretic, emmenagogue, gastroprotective, immunological, ophthalmic, purgative and many other biological activities (Garbacki et al. 1999; Senderski 2007; Chiru 2009; Pirvu et al. 2012). Medicinal properties have also been detected in seeds, which are used as mild laxatives; leaves used for production of cleansing facial spray and decoction with antirheumatic activity; and stems, which exhibit antibacterial activity (Garbacki et al. 1999; Stanojković et al. 2008; Pirvu et al. 2015).

Micromorphological traits of the structure of Asteraceae flowers are important clues for classification of the family. They can be taxonomic markers for genera and tribes (Angulo and Dematteis 2014). The authors have identified structures responsible for corolla pubescence in species of the genus Lessingianthus (Vernonieae), i.e. papillae and four trichome types. In almost all species, papillae were concentrated at the corolla lobe tips and trichomes were located on the adaxial surface at the apex of the corolla lobes. The occurrence of papillae only in the apical zone of corolla lobes and the absence of trichomes on the corolla were observed by Haratym and Weryszko-Chmielewska (2012). However, biseriate glandular trichomes were detected on corolla lobe tips in Helichrysum (Ascensão et al. 2001), whereas biseriate trichomes were observed on different corolla parts in Chamomilla and Inula (Sulborska 2011, 2013).

The cuticular patterns on the surface of ray flower petals were analysed in different tribes of Asteraceae. A crested pattern was found in all species from the tribe Mutisieae. However, no consistent cuticular patterns were described in other tribes (Baagøe 1977, 1978; Hansen 1991).

Different forms (lanceolate, ovate, ovate-lanceolate, linear) and sizes of anther apical appendages, different shapes (sagittate and cuneate) of the anther base, and the absence or presence of a style basal node were also distinguished as taxonomic features in Lessingianthus (Angulo and Dematteis 2014).

The stylar trichomes found in Asteraceae flowers play a role in secondary pollen presentation (Leins and Erbar 2006). A new micromorphological feature, i.e. cuticular patterns on stylar hairs, was observed in members of all tribes (44) of the Asteraceae family (Erbar and Leins 2015). The authors of those studies reported five types of cuticular striation: crested, triple, double, longitudinal and transverse patterns. Such cuticular patterns could be helpful in phylogenetic classification.

The distinctive features of plants from the Asteraceae family include the presence of secretory canals and different types of glandular and non-glandular trichomes, which have high taxonomic value. The number and distribution of secretory canals in the stem, which are usually lined with epithelium, are helpful in identification of genera (Metcalfe and Chalk
1972). Secretory canals have been observed in stems and leaves in many genera, inter alia Arnica (Kromer et al. 2016), Centaurea (Chiru et al. 2013), Inula (Sulborska 2007), Matricaria (Andreucci et al. 2008), Petasites (Haratym and Weryszko-Chmielewska 2012) and Rhaponticum (Łotocka and Geszprych 2004).

Glandular trichomes are widely distributed throughout the family Asteraceae (Metcalfe and Chalk 1972). Their structure may be (i) uniseriate: Aldama and Helianthus (Aschenbrenner et al. 2013; da Silva et al. 2014), (ii) biseriate: Chamomilla (Andreucci et al. 2008; Sulborska 2011), Helichrysum (Ascensao et al. 2001), Helianthus (Göpfert et al. 2010), Inula (Sulborska 2013), Stevia (Bondarev et al. 2010) and (iii) multiseriate, as those described in Sigesbeckia (Heinrich et al. 2002) and in Tussilago, which had a long biseriate stalk and a multicellular head (Muravnik et al. 2016).

Non-glandular trichomes in Asteraceae exhibit a wide range of structure types. Metcalfe and Chalk (1972) listed nine types of hairs in this group; in Centaurea, they described uniseriate trichomes with a long terminal cell. Furthermore, as reported by Chiru et al. (2013), Centaurea cyanus has several types of nonglandular (protective) trichomes. With its white cobweb-like pubescence consisting of non-glandular trichomes covering the leaves and stem, the plant looks dull and grey (Rzymowska and Skrzyczyńska 2007; Chiru et al. 2013).

Although many studies have described the medicinal properties of different species from the Centaurea genus, the microstructure of their organs used as herbal raw material and secretory tissues has been rarely investigated. Some information provided by microscopic analyses of the vegetal product Cyani herba was only published by Chiru et al. (2013). Given the importance of this species as a medicinal plant, the present study consisted in micromorphological, ultrastructural and histochemical analyses of aboveground organs of C. cyanus and their secretory structures, i.e. glandular trichomes and ducts, which are the main source of bioactive substances. Moreover, we considered the taxonomic value of some features of the floral micromorphology, secretory structures, nonglandular trichomes and calcium oxalate crystals, which may be useful for evaluation of the quality (falsification) of medicinal raw materials.

\section{Material and methods}

The aboveground organs of Centaurea cyanus were examined at the full flowering stage in June and July 2014-2016. The plant material was obtained from the Botanical Garden of Maria Curie-Skłodowska University of Lublin, Poland (51 ${ }^{\circ}$ $15.629^{\prime} \mathrm{N}$ and $22^{\circ} 30.975^{\prime} \mathrm{E}$ ).

Flowers, bracts, stems (the middle part of the 6th and 7th internode) and leaves (from the 7th internode) were observed with the use of stereoscopic (SM), light (LM), fluorescence 
(FM), scanning electron (SEM) and transmission electron (TEM) microscopy. Moreover, various histochemical tests were performed on transverse sections of stems.

\section{SM and LM}

Preliminary examination of fresh material (flowers, bracts, stems and leaves) was performed using a stereoscopic microscope equipped with a Nikon Coolpix 4500 camera and a Nikon Eclipse 400 light microscope.

At the floral stage, pollen grains were collected from the anther tube, spread on a slide, and stained with basic fuchsin. The size of the pollen grains $(n=100)$ was measured with a light microscope equipped with a calibrated ocular micrometer.

\section{Histochemical tests and FM}

Transverse sections for these analyses were taken from the middle area between the 6th and 7th internodes of freshly collected stems. Only substances produced by secretory ducts were analysed. Fresh unfixed and unstained sections were used as a negative control. The classes of the tested metabolites are listed in Table 1. The observations were carried out with the use of a Nikon Eclipse 400 light microscope. Secondary fluorescence of plant metabolites was examined using antimony trichloride, magnesium acetate and aluminium trichloride under a Cy5 filter (excitation light-590$650 \mathrm{~nm}$ and a barrier filter-wavelength $663-738 \mathrm{~nm}$ ). The autofluorescence of lipids was demonstrated using a fluorescein isothiocyanate-FITC filter (excitation light-590 $650 \mathrm{~nm}$ and a barrier filter-wavelength $663-738 \mathrm{~nm}$ ) (Huang et al. 2008). Images were obtained with the use of a digital camera Nikon Fil and NIS - Elements Br 2 software.

\section{SEM}

Small segments of stems, bracts and flowers $(n=10)$ were fixed in a $4 \%$ glutaraldehyde solution in $0.1 \mathrm{M}$ phosphate buffer ( $\mathrm{pH}$ 7.0). Subsequently, the samples were incubated for $12 \mathrm{~h}$ at room temperature. To wash the plant material, the same buffer was used four times at 20-min intervals. The samples were dehydrated in ethanol series $(30,50,70,90$ and $95 \%$ ) and submerged in absolute alcohol three times. After transferring to acetone, the plant material samples were critical point dried in liquid $\mathrm{CO}_{2}$ using Bal-Tec $\mathrm{CPD} 030$. The prepared fragments of plant organs were placed on a doublesided carbon tape on stubs. A Polaron SC 7640 sputter coater was used for covering the specimens with a $10-\mu \mathrm{m}$-thick gold layer. A scanning electron microscope TESCAN/VEGA LMU at an accelerating voltage of $30 \mathrm{kV}$ was used to examine the material.

\section{TEM}

Small sections $(5 \times 5 \mathrm{~mm})(n=10)$ of $C$. cyanus stems were isolated and fixed in a mixture of $3.5 \%$ glutaraldehyde and $3.5 \%$ paraformaldehyde in $0.1 \mathrm{M}$ phosphate buffer (PBS) with

Table 1 Metabolite classes, reagents, reaction colours and references of the methodologies used in the histochemical and fluorescence tests

\begin{tabular}{|c|c|c|c|}
\hline Metabolite classes & Reagents & Reaction colours & References \\
\hline \multicolumn{4}{|l|}{ Lipids } \\
\hline \multirow[t]{2}{*}{ Total } & $\begin{array}{l}\text { Sudan IV } \\
\text { Sudan Red B }\end{array}$ & $\begin{array}{l}\text { Orange } \\
\text { Red }\end{array}$ & $\begin{array}{c}\text { Johansen 1940; Lison } 1960 \\
\text { Brundrett et al. 1991; } \\
\text { Hohmann et al. } 2001\end{array}$ \\
\hline & Autofluorescence (FITC) & Green & Huang et al. 2008 \\
\hline Neutral and acidic lipids & Nile Blue & Blue & Jensen 1962 \\
\hline \multicolumn{4}{|l|}{ Terpenoids } \\
\hline Essential oil and resin-oil & Nadi reagent & Purple & David and Carde 1964 \\
\hline Essential oil & Neutral Red & Red & Kirk 1970; Clark 1981 \\
\hline Steroids & Antimony trichloride & Yellow (under UV) & Mace et al. 1974 \\
\hline Sesquiterpenes & Conc. sulphuric acid & Yellow & Cappelletti et al. 1986 \\
\hline \multicolumn{4}{|l|}{ Phenolic compounds } \\
\hline General & Ferric trichloride III & Black & Johansen 1940 \\
\hline Tannins & Potassium dichromate & Brown & Gabe 1968 \\
\hline Flavonoids & Aluminium trichloride & Yellow (under UV) & Charrière-Ladreix 1976 \\
\hline Flavonoids & Magnesium acetate & Yellow (under UV) & Charrière-Ladreix 1976 \\
\hline \multicolumn{4}{|l|}{ Polysaccharides } \\
\hline General & PAS (periodic acid-Schiff's) reagent & Pink & Mcmanus 1948 \\
\hline Pectins & Ruthenium Red & Crimson & Johansen 1940 \\
\hline
\end{tabular}


$\mathrm{pH} 7.2$ for $1 \mathrm{~h}$ at room temperature. Subsequently, the specimens were rinsed in $0.1 \mathrm{M}$ PBS and additionally fixed in a $4 \%$ aqueous solution of osmium tetroxide for $24 \mathrm{~h}$ at ambient temperature. Then, the samples were rinsed in distilled water, dehydrated with a graded ethanol series, and saturated in 1:3, 1:1 and 3:1 mixtures of LR White resin and acetone for $3 \mathrm{~h}$ each. Eventually, the prepared specimens were embedded in LR White resin and cut into ultra-thin sections of 60 to $90 \mathrm{~nm}$ using the Reichert Ultracut $\mathrm{S}$ microtome. The sections were loaded onto 100-mesh copper grids coated with Formvar (1\% in ethylene dichloride) and stained with uranyl acetate and lead citrate (Reynolds 1963; Karnovsky 1965). The ultrastructure was analysed with the use of a Tesla BS 500 transmission electron microscope, and the viewed images were photographed on a Foton TN-12 electron microscope film.

\section{Results}

\section{Morphology and anatomy of flowers}

The Centaurea cyanus was found to have a monopodial inflorescence. The flowers formed a single flower-like capitulum surrounded by involucral bracts (Fig. 1a). The peripheral florets were sterile, ligulate and funnel-shaped, and their colour ranged from blue through light violet to dark violet (Fig. $1 \mathrm{a}-\mathrm{c})$. Their epidermis was composed of elongated cells with distinctive cuticular striae forming a characteristic crested pattern on their surface (Fig. 1d). The inner part of the inflorescence was formed by disc florets (Fig. 1a, b, e). They were composed of five fused petals forming a tubular corolla (Fig. 1e), with adaxial epidermis at the top of the lobes covered with densely distributed approximately $27-\mu \mathrm{m}$-long papillae forming a violet-blue protuberance resembling a hemispherical surface (Fig. 1f, g). As in other epidermal cells, the vacuoles of the papillae contained anthocyanins. The anthers of five stamens formed a tube, which protruded from the corolla tube (Fig. 1e, h, k). The anther tube was approximately $47 \mathrm{~mm}$ long, and almost $30 \%$ of its length consisted of flattened apical parts of pink-violet connectives (Fig. 1e, h, i, k). Spirally twisted multicellular structures fused to the lower parts of the anthers (Fig. $11 \mathrm{n}, \mathrm{o}$ ). Additionally, there were five separated white filaments (Fig. 1h-1). Below the top of the filaments, there were hair-like structures with longitudinal cuticular striae forming a crown (Fig. 1 1, m). These hairs contained cytoplasm with numerous granularities and cell nuclei (not shown). The upper part of the style and the outer part of the dichotomous stigma formed a secondary pollen presenter (Fig. 1p, q). Stylar hairs and numerous papillae were located on the surface of the presenter. The area of the style below the tip was covered by long brushing hairs and the tip and abaxial surface of the stigma were occupied by smaller and shorter papillae (Fig. 1p, q). The papillae were expanded at the base
Fig. 1 Characteristics of Centaurea cyanus flowers. a Inflorescence with marginal ray florets and central disc florets $\mathbf{b}$ Disc florets. $\mathbf{c}$ Ray floret. d Surface of the ray floret corolla with crested cuticular striae. e Disc floret. f Apical part of disc floret corolla lobes with papillae (asterisks) stained with anthocyanins. g Papillae on the corolla lobes. h Disc floret androecium with visible connectives, filaments and hair-like structures (arrows). i Apical part of a connective stained with anthocyanins. j Part of the androecium with filaments and hair-like structures (asterisks) in the form of a crown. $\mathbf{k}$ Transverse section through a disc floret with a visible androecium and hair-like structures (arrows). I Hair-like structures (arrowheads) on the filaments and spiral structures (arrows) on the basal part of the anthers. $\mathbf{m}$ Surface of a hair-like structure with longitudinal cuticular striae. $\mathbf{n}, \mathbf{o}$ Parts of the stamen with hair-like (arrowheads) and spiral (arrows) structures. p, q Parts of the pistil with brushing hairs on the style and papillae on the stigma. $\mathbf{r}$ Section across elongated stigma epidermal cells stained with anthocyanins (asterisks) without papillae. s Tricolporate pollen grains. $\mathbf{t}$ Pollen grains stained with basic fuchsin in different views: equatorial view (upper) and polar view (lower). $R f$ ray flower, $D f$ disc flower, $P$ pappus, $C t$ corolla tube, $C l$ corolla lobes, Sta stamens, $C$ connective, $A$ anthers, $F$ filaments, Sti stigma, Sty style, $B h$ style brushing hairs, $P a$ papillae, $P g$ pollen grains

and pointed at the upper part. The stylar hairs were covered by longitudinal cuticular striae, similarly to the filament hairs (not shown). During maturation of the flower, the presenter presses through the centre of the anther tube and sweeps out the pollen released from the anthers. Retention of pollen grains is facilitated by the oblique orientation of the trichomes to the main axis of the style. The length of the part of the style with the presenter trichomes was $0.56-0.73 \mathrm{~mm}$ (on average $0.66 \mathrm{~mm}$ ), which is about $5 \%$ of the entire length of the style. The adaxial epidermis of the stigma was composed of elongated cells, among which we did not find papillae (Fig. 1r). The stigma cells and the anther tube were pink-violet, which indicated the presence of anthocyanins.

The pollen grains of the C. cyanus are tricolporate, isopolar and radially symmetric (Fig. 1q, s, t). They are subtriangular in the polar view and compressed oval in the equatorial view. The length of the polar axis $(\mathrm{P})$ ranges from 30.48 to $41.94 \mu \mathrm{m}$ (on average $35.03 \mu \mathrm{m}$ ) and the equatorial axis (E) ranges from 24.13 to $30.48 \mu \mathrm{m}$ (on average $27.39 \mu \mathrm{m}$ ). They represent medium-sized grains. Based on the ratio of the length of the polar axis to the equatorial diameter $(\mathrm{P} / \mathrm{E})$, which is on average 1.28 , the pollen grains in the species are classified into the subprolate pollen type.

The $C$. cyanus inflorescences subtended an involucre of overlapping bracts with serrate margins and toothed tips (Fig. 2a-c). During development of the inflorescence, the edged parts of the bracts changed colour from the base to the apex. Their visible portion became dark brown tanned (Fig. 2b, c). On the edges of each tooth of the bract, there were numerous pointed unicellular nonglandular trichomes (Fig. 2d, e). The abaxial surface of the bract was covered by two types of non-glandular trichomes. One type was represented by short hook-shaped unicellular hairs (Fig. 2d, f). Their sharp ends pointed 

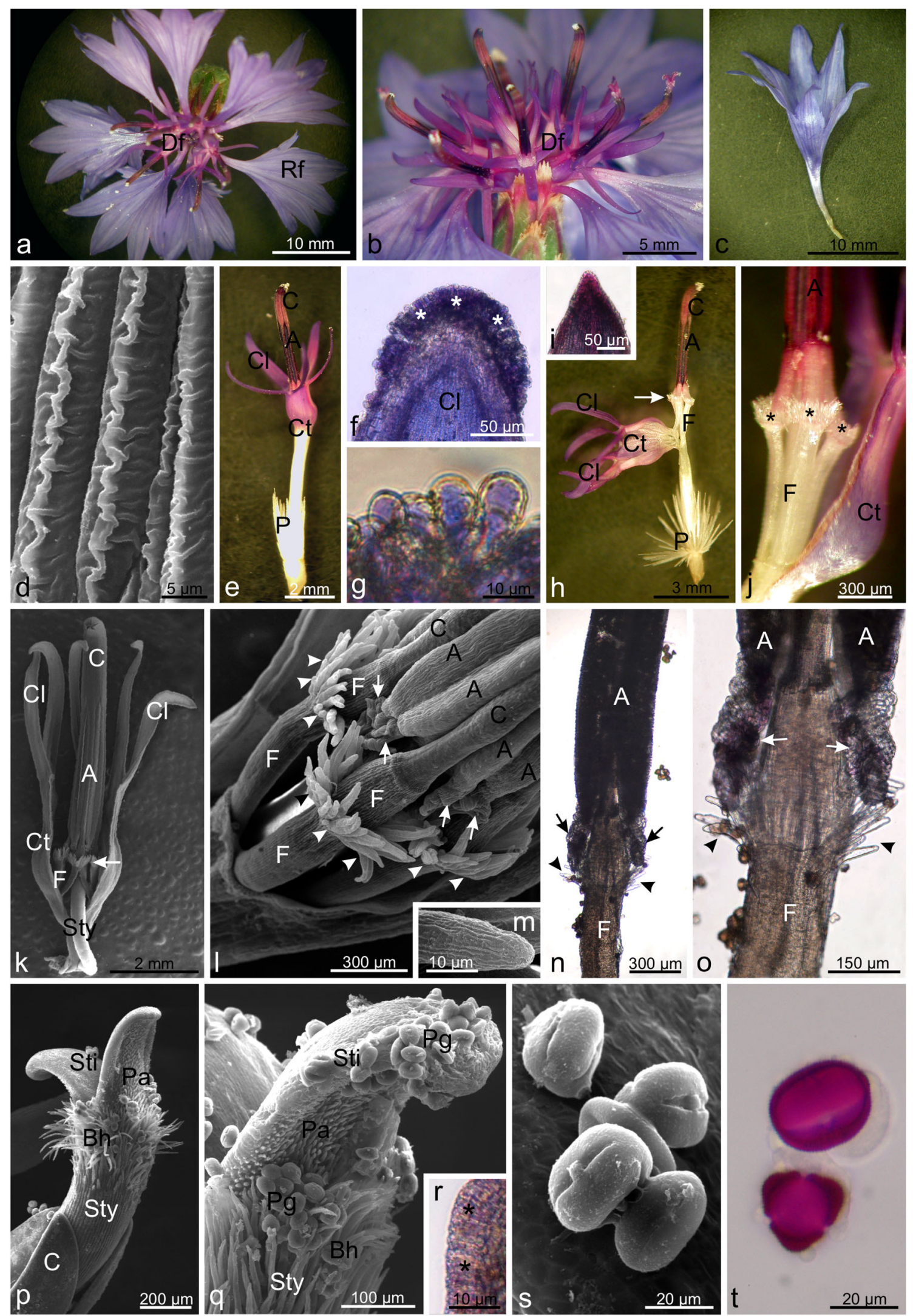

towards the apex of the bract. Another type comprised long and tangled white multicellular hairs (Fig. 2g, h).
A few (7-10) glandular trichomes were also found in the central part of the abaxial surface of the bracts (Fig. 2j, k). 
They had a characteristic bilayered structure and consisted of a pair of basal cells, a pair of stalk cells, and 6 to 7 vertical tiers of glandular cells (Fig. 2j, k). The length of the trichomes was around $90 \mu \mathrm{m}$. During the observations, no pore or crack through which the secretion could be exuded was noticed.

Single calcium oxalate crystals were visible in the abaxial epidermal cells of the central part of the bract (Fig. 2g-i). These deposits represented the prismatic type and were approx. $10 \mu \mathrm{m}$ in length and $5 \mu \mathrm{m}$ in width. Moreover, numerous stomata were found in this epidermis of the bracts (Fig. 2h).

\section{Morphology and anatomy of stems}

The surface of the stem exhibited a densely pubescent indumentum (Fig. 3a, c, e, f). It mainly consisted of long multicellular trichomes (Fig. 3c), among which shorter 8-9celled non-glandular trichomes were found (Fig. 3b-d). Their basal cells were much wider than the apical ones. Their erect trichomes were inclined towards the surface of the organ (Fig. $3 b-d)$. Furthermore, there were sporadic biseriate glandular trichomes, the same as those on the surface of the bracts (Fig. 3f).

The stem had a pentagonal shape, which was visible in the cross section (Fig. 3e, f). There was one layer of epidermal cells with a thick cuticle. Below, there was a multilayered cortex, which most often consisted of one layer of collenchyma and several layers of parenchymatous cells (Fig. 3e-g). The collenchyma in the stem corners was much thicker and consisted mostly of 5-6 layers of cells (Fig. 3e, f). Vascular bundles of various sizes were embedded in the stele parenchyma and surrounded by a sheath of sclerenchyma (Fig. 3e-g). Individual reservoirs (ducts) with yellowish secretion were located in the cortex parenchyma outside the endodermis. The ducts were mainly located above the phloem and the outer part of the sclerenchyma sheath (Fig. 3g, h). The ducts were surrounded by a single layer of epithelium consisting of 5-6 cells. Their diameter was approximately $3.5 \mu \mathrm{m}$.

\section{Histochemistry of stem secretory ducts}

The histochemical assays and fluorescence microscopy studies showed that the secretion of the stem secretory ducts contained different secondary metabolites: lipids, essential oil, terpenoids and phenolic compounds (tannins and flavonoids).

In control samples submerged in water, the secretion in the ducts was yellowish (Fig. 3g, h). The presence of lipids in the secretory product was detected after application of Sudan IV and Sudan Red B, which stained total lipids orange or reddish, respectively (Fig. 3i, j). After the Nile Blue treatments, acid lipids were visualised by blue colour (Fig. 3k). The presence of lipid substances was also confirmed by green autofluorescence under the FITC filter set (Fig. 31). Essential oil contained in the secretion was stained red upon the Neutral Red treatment (Fig. $3 \mathrm{~m}$ ). We also showed the presence of tannins, which were characterised by light brown colour when stained with potassium dichromate (Fig. 3n). We observed yellowish secondary fluorescence after using aluminium trichloride and magnesium acetate as fluorochromes, confirming the presence of flavonoids (Fig. 3o, p). The presence of terpenes containing steroids was indicated by intense yellowish fluorescence under UV light (Fig. 3q).

The reactions were negative or similar to the control after application of the other histochemical assays based on the use of periodic acid-Schiff's reagent, Ruthenium Red, Nadi reagent, concentrated sulphuric acid and ferric trichloride.

\section{Morphology and anatomy of leaves}

Centaurea cyanus leaves are lanceolate with a pointed apical part (Fig. 4a). Similar to the bract and stem surfaces, the adaxial surface of the leaf was covered by long nonglandular trichomes forming a densely pubescent indumentum (Fig. 4b). These uniseriate and multicellular trichomes had a long thread-like terminal cell (not shown). On the abaxial leaf surface, we observed two types of non-glandular trichomes. The first type was represented by sparse long uniseriate and multicellular nonglandular trichomes. The second type comprised much shorter (approximately $107 \mu \mathrm{m}$ long) pointed nonglandular trichomes composed of several (6-8) thickwalled cells with an enlarged double-row base, similar to those found on the stem. They were located on the midrib surface (Fig. 4c-e). The cells of these trichomes exhibited light brown granular content (Fig. 4d, e). Additionally, curved, live non-glandular trichomes composed of 4-6 cells with a length of approx. $40 \mu \mathrm{m}$ were visible on the leaf margins (Fig. 4f).

The cuticle-covered cells on both epidermis (upper and lower) surfaces had thick outer walls. The next layer of tissue consisted of cylindrical, elongated, chloroplast-rich cells forming the palisade parenchyma. Below, there was spongy parenchyma with irregularly shaped cells. Vascular bundles were arranged in the middle part of the parenchyma. The bundles from the top and bottom were delimited by a sclerenchymatous sheath (Fig. 4g, h). The largest vascular bundle was located in the central region of the leaf blade. A single secretory duct, similar to those found in the stem, was visible in the parenchyma below the lower layer of the sclerenchyma sheath surrounding the main bundle (Fig. 4g, h).

\section{Ultrastructure of stem secretory ducts}

The ultrastructure of epithelial cells located around the secretory duct in the stem was analysed. The duct is a tubular 

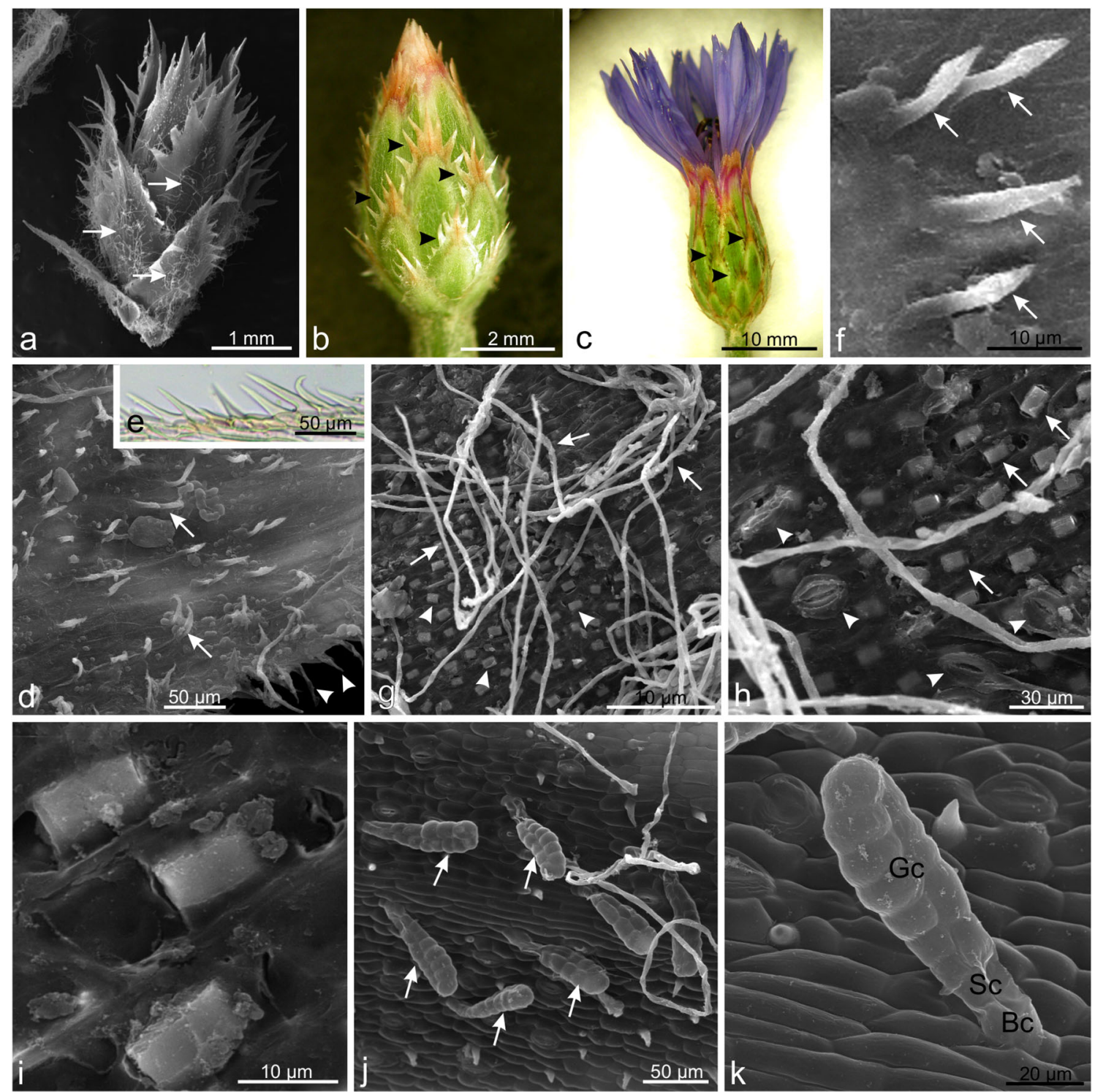

Fig. 2 Microstructure of C. cyanus bracts. a, b Bracts on the floral buds with visible non-glandular trichomes (arrows) forming an indumentum and pointed white and beige trichomes at the edges (arrowheads). c Bracts during anthesis with brown coloured trichomes (arrowheads) on the edges. d Abaxial surface of the apical part of the bract with short unicellular pointed trichomes (arrows). e Portion of bract edges with pointed (double-arrows) and hook-shaped (arrow) trichomes. f Non-

glandular, hook-shaped trichomes (arrows) on the abaxial surface of the bract. $g$ Surface of the central abaxial part of the bract with long dead nonglandular trichomes (arrows) and calcium oxalate crystals (arrowheads). h Calcium oxalate crystals (arrows) and stomata (arrowheads). i Calcium oxalate crystals. $\mathbf{j}$ Glandular trichomes (arrows) on the abaxial bract surface. $\mathbf{k}$ Biseriate glandular trichome with a pair of basal cells (bc), a pair of stalk cells (sc), and 6 to 7 vertical tiers of glandular cells $(\mathrm{gc})$

structure lined by one layer of epithelial secretory cells (Fig. 5a, b). The secretory cells differed from the surrounding parenchyma cells - they were smaller and had abundant organelles. In turn, the parenchyma cells were substantially bigger and were filled with a huge vacuole. It was evident that every secretory cell was in another secretory phase (Fig. $5 \mathrm{a}, \mathrm{b})$. Older secretory cells had released a secretion and were in the postsecretory stage. In these cells, the cytoplasm was limited to the peripheral region, and the cell interior was filled with a large central vacuole containing flocculent material with moderate electron density (Fig. 5b). The cell protoplast was largely degraded, and numerous vesicles with different degrees of osmophilicity were accumulated mainly along the cell wall (Fig. 5d-f). These secretory cells were characterised by the presence of multivesicular or membranous bodies, probably filled with lipophilic compounds, as the secretion stained with e.g. Sudan also revealed the presence of these compounds (Fig. 5d-f). In turn, younger cells that were in the secretory stage had a visible nucleus and plastids (Fig. $5 \mathrm{a}, \mathrm{c})$. Moreover, there were small vacuoles filled with a strongly osmiophilic non-soluble fraction of a substance representing phenolic compounds, which was confirmed by 

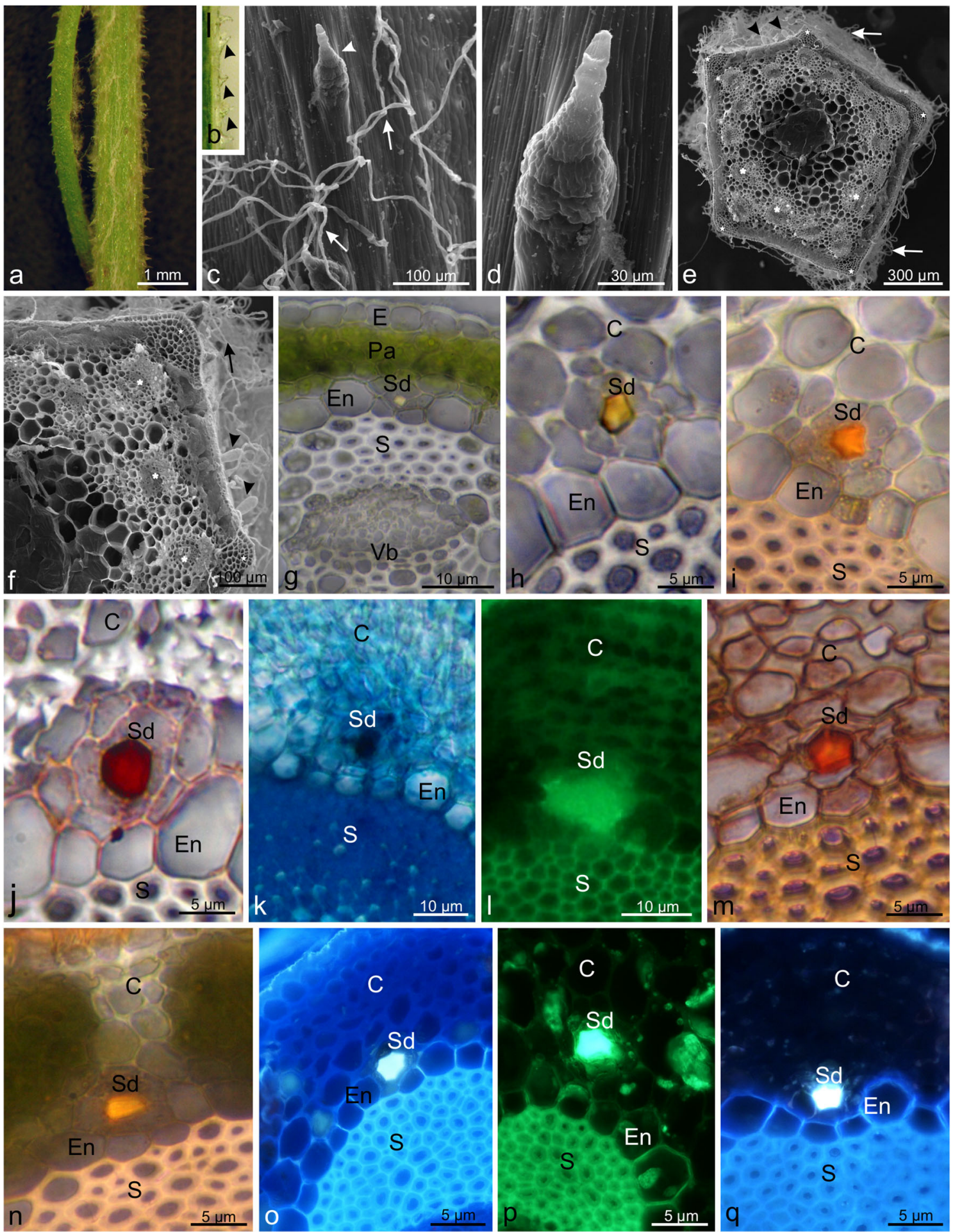

Fig. 3 Characteristics of C. cyanus stems and presence of secondary metabolites in the secretory ducts. a Portion of a $C$. cyanus stem covered with trichomes. b Short non-glandular trichomes (arrowheads) on the stem. Scale bar $=250 \mu \mathrm{m}$. c Surface of the stem with long nonglandular trichomes forming a densely pubescent indumentum (arrows) and short pyramidal trichomes (arrowhead). d Short trichome on the stem surface. e, f Transverse sections through the stem with visible vascular bundles (asterisks), collenchyma in the corners (stars), and non-glandular (arrows) and biseriate glandular (arrowheads) trichomes on the surface. $\mathbf{g}, \mathbf{h}$ Portion of a transverse section through the stem with a visible secretory duct with yellow secretion. i Lipophilic compounds in the secretion of the secretory duct stained orange with Sudan IV. $\mathbf{j}$ Lipids in the

secretory duct stained red with Sudan Red B. k Acid lipids in the secretory duct stained dark blue after application of Nile Blue I Green autofluorescence under FITC indicating the presence of lipid substances. $\mathbf{m}$ Red coloured essential oil after treatment with Neutral Red. n Yellow-brown colour of tannins stained with potassium dichromate. o Secondary fluorescence of flavonoids observed after application of aluminium trichloride under the Cy5 filter. p Yellowish fluorescence of flavonoids observed addition of magnesium acetate under the Cy5 filter. q Yellowish fluorescence of steroids stained with antimony trichloride and observed under the Cy5 filter. $S d$ secretory ducts, $E$ epidermis, $S$ sclerenchyma, $C$ collenchyma, $P a$ cortex parenchyma, $V b$ vascular bundle, $E n$ endodermis 
Fig. 4 Microstructure of C. cyanus leaves. a Adaxial leaf surface covered with a white densely pubescent indumentum. b Long, white non-glandular trichomes on the adaxial leaf surface. $\mathbf{c}$ Portion of the abaxial leaf surface with short non-glandular trichomes (arrows) on the midrib. d, e Live non-glandular trichomes with thick-walled cells on the abaxial leaf surface. f Short nonglandular trichomes (arrows) on the leaf margin. g Portion of a transverse section through the leaf with a visible vascular bundle and secretory duct (arrow) in the midrib. $\mathbf{h}$ Secretory duct with yellow secretion (arrow) above the sclerenchyma sheath of vascular bundle. $V b$ vascular bundles, $S$ sclerenchyma sheath, $P a$ mesophyll, Ead adaxial epidermis, Eab abaxial epidermis
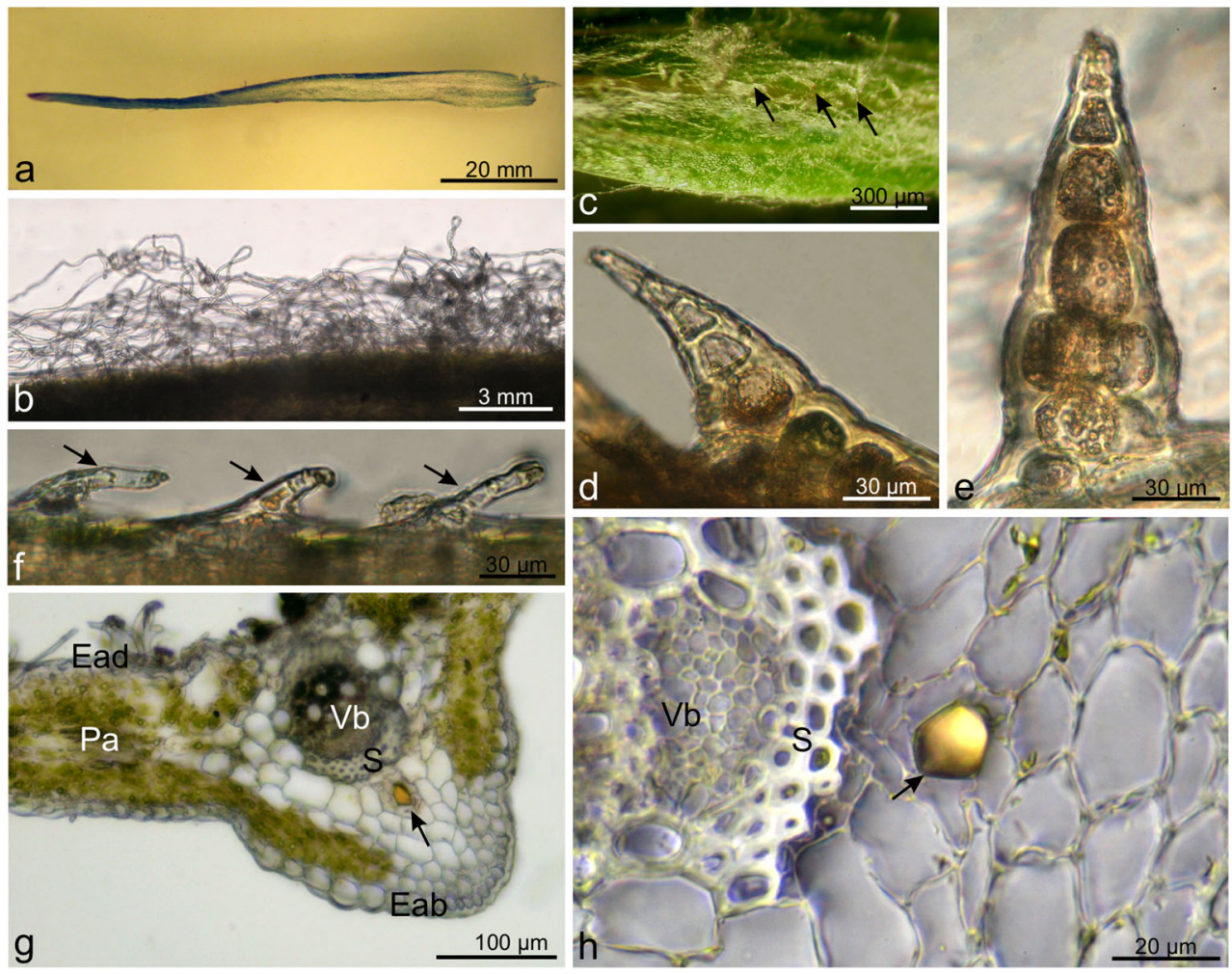

the histochemical tests (Fig. 5c). The cytoplasm also contained myelin-like bodies probably derived from the smooth endoplasmic reticulum or formed by the disruption of plastid membranes (Fig. 5c). Long chains of granular lipophilic material were present between the cytoplasm and the cell wall (Fig. 5g). The vesicles with various substances transported them through the cytoplasm and fused with the cell membrane via endocytosis. Dark elaioplasts enriched with lipophilic compounds were observed in the cytoplasm (Fig. $5 \mathrm{~h}, \mathrm{i})$. No plasmodesmata were observed in the walls of the epithelial cells of the secretory ducts. The microscopic analyses suggested that the ducts developed through separation (middle lamella detachment) of the walls of the central cells, which were pushed outward. Furthermore, the presence of epithelial cells surrounding the duct confirmed their schizogenous origin.

\section{Discussion}

Recently, Centaurea has become the subject of intensive research, as several species from this genus have medicinal properties. Many studies on phytochemical characterisation have been conducted (e.g. Karamenderes et al. 2007; Küpeli Akkol et al. 2009; Aktumsek et al. 2011; Luković et al. 2013), yet the structure of these species has still been poorly described. Although chemical analyses and molecular data have greatly contributed to establishment of the species phylogeny, macro- and micromorphological features are still an irreplaceable source of information for this type of study.

In the C. cyanus disc flowers, we observed densely distributed papillae at the top of the corolla lobes. Similar location of papillae has been reported in flowers of other Asteraceae species, e.g. representatives of the genera Petasites (Haratym and Weryszko-Chmielewska 2012), Lessingianthus (Angulo and Dematteis 2014), Gazania and Cirsium (personal observations). The presence of papillae in the apical zone of corolla lobes seems to be a characteristic trait of many Asteraceae species.

The surfaces of ray flower petals in C. cyanus (Cardueae) had a crested cuticular pattern, similar to that described earlier by other authors in the tribes Arctotideae, Calenduleae, Cichorieae, Inuleae and Mutisieae (Baagøe 1977, 1978; Hansen 1991; Koch et al. 2013). For the first time, our results provide information about such cuticular sculpture in the ray flowers in C. cyanus. A longitudinal cuticular pattern was detected on the stylar and filament hairs in the $C$. cyanus flowers. Our observations are in agreement with the data on the cuticular pattern on stylar hairs reported by Erbar and Leins (2015) for the Cardueae tribe. The longitudinal pattern on stylar hairs is observed in Asteraceae relatively frequently; for instance, Erbar and Leins (2015) have described this trait in 17 of all the 44 tribes.

In our study, we have demonstrated that $C$. cyanus stamens were equipped with a mechanism that facilitated the release of 
Fig. 5 Ultrastructure of the secretory ducts in the $C$. cyanus stem. a, b Secretory ducts (black asterisks) surrounded by a layer of epithelial cells (white asterisks). Note that every glandular cell was in different secretory phases. a, c Younger cells of the epithelium had a visible nucleus and plastids. b Older epithelial cells had cytoplasm limited to the peripheral region and the cell interior filled with a large central vacuole containing flocculent material with moderate electron density. c Note myelin-like bodies (arrow) in the cytoplasm. d-f In the older cells, a visible degraded protoplast with numerous large vesicles with different degrees of osmophilicity accumulated along the cell wall. Note the small lipid bodies (arrows) and multivesicular or membranous bodies. $\mathbf{g}$ Long chains of granular lipophilic material (arrows) visible between the cytoplasm and the cell wall. $\mathbf{h}, \mathbf{i}$ In the cytoplasm, visible dark elaioplasts enriched with lipidic substances. $N$ nucleus, $P$ plastids, $E R$ endoplasmic reticulum, $V$ vacuoles, $V e$ vesicles, $M b$ multivesicular and membranous bodies
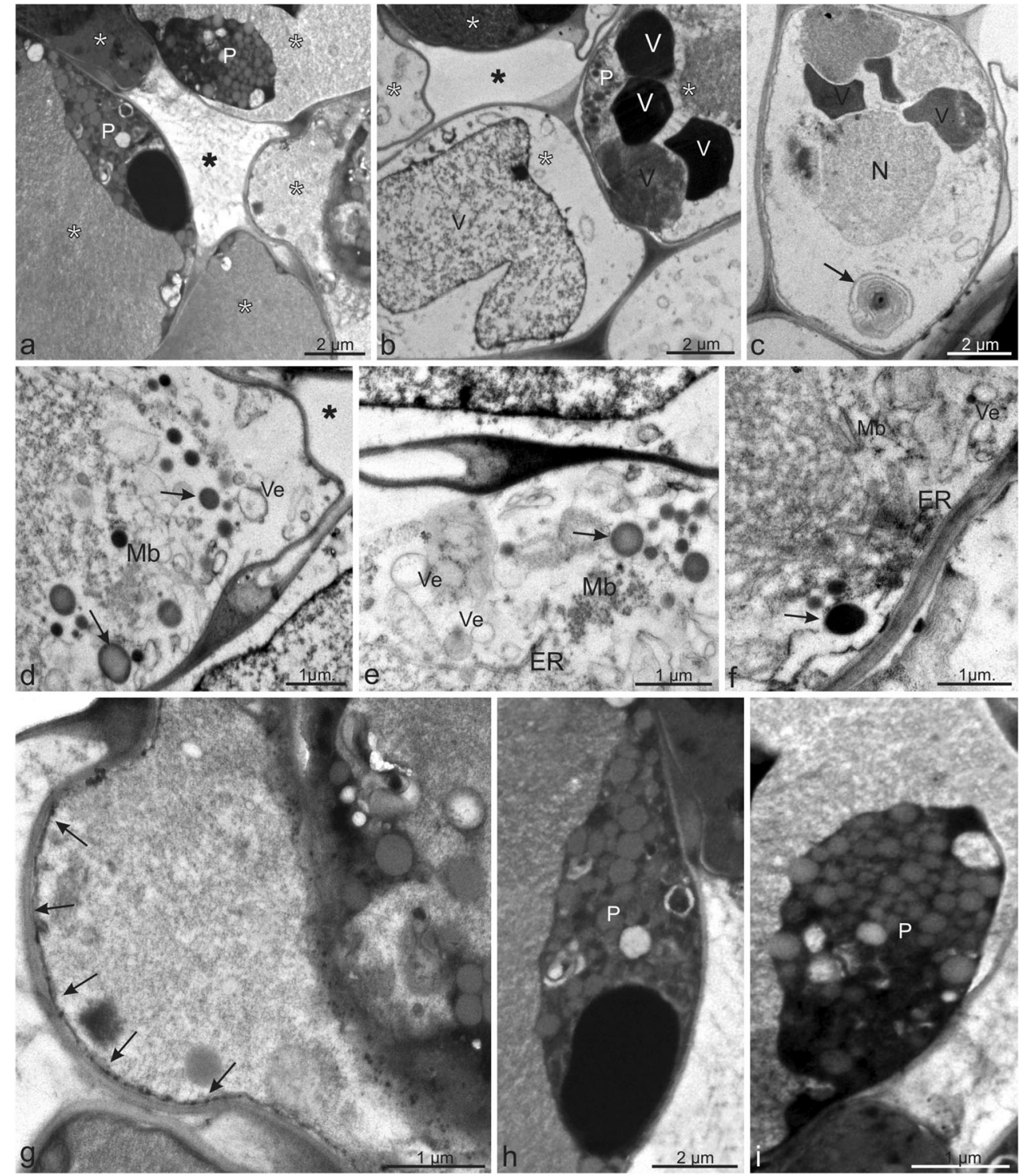

pollen grains. In our opinion, the spirally twisted structures present at the bottom of the anthers might be involved in their shrinkage and cracking, as the anther tube shrank in response to an insect touch. In turn, the numerous concentrically arranged hair-like structures located on the filaments probably protect nectar against water flow and thus nectar dilution and/ or drying out.

The morphology and distribution of trichomes are regarded as a representative feature in the Asteraceae family (e.g. Ciccarelli et al. 2007; Hayat et al. 2009; Rahiminejad et al. 2010; de Andrade et al., 2014a, b). The trichomes described in C. cyanus in this study represent four types of non-glandular trichomes (one type of longer hairs and 3 types of shorter trichomes) and one type of glandular trichomes (biseriate trichomes). All these trichome types were located on the stems and bracts, whereas only long and short non-glandular hairs were visible on the leaves. The density of the trichomes varied. In turn, Chiru et al. (2013) observed three types of non-glandular trichomes in C. cyanus. While, Luković et al. (2013) described two types of these trichomes in Centaurea sadleriana. We have demonstrated that the glandular trichomes found on the epidermal surface of $C$. cyanus bracts have 6-7 tiers. Werker et al. (1994) observed glandular trichomes on the surface of Artemisia dracunculus with the same number of cell layers. Biseriate trichomes differing in the number of cells and size from those present in $C$. cyanus have been described in many other species, e.g. Artemisia annua (Duke and Paul 1993), Chamomilla recutita (Sulborska 2011), Helichrysum aureonitens (Afolayan and Meyer 1995), Inula helenium (Sulborska 2013), Sigesbeckia jorullensis (Heinrich et al. 2002) and Stevia rebaudiana (Bondarev et al. 2010).

In the abaxial epidermal cells of the bracts in C. cyanus, we observed numerous prismatic calcium oxalate crystals. 
Crystals are present in different plant organs including leaves, stems, roots and fruits as well as various floral organs such as ovaries, anthers, petals, sepals or bracts, and nectaries (Dane et al. 2000, Meric, 2009a, b; Jacobs et al. 2010; Horner 2012). Several studies have shown their variety in the Asteraceae family. Some species contain raphides (Kartal 2016), druses (Nwosu et al. 2013), styloids (Meric, 2009a, b) and prismatics (Meric 2009b). The investigations conducted by Kartal (2016) revealed that styloids and prismatics are the most common forms of crystals found in the members of the Cardueae tribe. The present study examined the morphology and location of $\mathrm{CaO}_{\mathrm{x}}$ crystals in $C$. cyanus, which also belongs to the Cardueae tribe. Their prismatic shape was similar to that of crystals found in other species of Centaurea-C. iberica and C. salonitana (Kartal 2016). Although the distribution and shapes of calcium oxalate crystals can be affected by biological, chemical and physical conditions, their formation is believed to be controlled genetically; thus, they are species specific (Prychid and Rudall 1999; Franceschi and Nakata 2005). Therefore, their types as well as presence or absence can be used as taxonomic characters (Kuo-Huang et al. 2007; Horner et al. 2009, 2012). Their possible roles can include regulation of calcium concentration, detoxification of heavy metals or oxalic acid, light gathering and reflection, protection against herbivores, and strengthening of tissues (Franceschi and Nakata 2005; Kuo-Huang et al. 2007; Cote and Gibernau 2012). The results of the latest research have shown that these crystals can also be an important internal source of $\mathrm{CO}_{2}$ used by plants for the so-called alarm photosynthesis (Tooulakou et al. 2016).

The secretory ducts of $C$. cyanus were formed schizogenously: the schizogenous corner-space was created by gradual separation of neighbouring cell walls anticlinal to the reservoir along the middle lamella. The development of this structure in the C. cyanus stems and leaves agrees with the observation made in other species from the Asteraceae family such as Arnica montana, Flourensia campestris, F. oolepis, Matricaria chamomilla or Rhaponticum carthamoides (Łotocka and Geszprych 2004; Andreucci 2008; Silva et al. 2015; Kromer et al. 2016). We found secretory ducts in the stems of $C$. cyanus only in the region of endodermis opposite the phloem. However, we did not detect medullary canals, which were found in Centaurea by Metcalfe and Chalk (1972). The anatomy of these internal secretory structures is similar to that of other species in the same family, e.g. Inula helenium (Sulborska 2007). Moreover, similar to C. cyanus, also in C. sadleriana (Luković et al. 2013), only a single canal was present between parenchymatic cells located close to the phloem, while usually two cavities were detected in I. helenium - one on each side of the bundle. In I. helenium, sometimes even four cavities accompanied a single vascular bundle, i.e. two on each of its sides. The presence of only one secretory reservoir was rare. However, in another species from the Asteraceae family_Petasites hybridus, secretory ducts were observed in the cross section of scaly leaves in the same position as those in the C. cyanus (Haratym and WeryszkoChmielewska 2012). Since they are located close to the phloem in various species, secretory ducts may aid the transfer of organic material by sieve tubes (Williams 1954). Moreover, these ducts in the Cardueae tribe can help to distinguish between single species. Fritz and Saukel (2011) revealed that the ratio between the diameter of the duct and the size of surrounding parenchyma cells is an important feature in identification of species in a given genus.

The results of the histochemical assays and fluorescence microscopy revealed that the material produced by the epithelium cells of the secretory ducts of Centaurea cyanus have a complex nature. Most of the substances produced by the C. cyanus are lipophilic and lipidic, which was indicated by the positive reactions with Sudan IV, Sudan Red and Nile Blue and by the autofluorescence observed with the use of the FITC filter. Production of lipids by the epithelium cells of the secretory ducts was also found in Matricaria chamomilla, Santolina ligustica, and species from the Ophryosporus genus (Pagni et al. 2003; Andreucci et al. 2008; Plos et al. 2011), which belong to the same family as the $C$. cyanus. The presence of essential oil was confirmed by the reaction with Neutral Red. Numerous species in the Asteraceae family produce these metabolites as well, e.g. Matricaria chamomilla (Andreucci et al., 2008), Pteronia incana (Hulley et al. 2010), and different species of Baccharis (Budel et al. 2012). Moreover, the reaction with potassium dichromate facilitated detection of tannins in the C. cyanus secretion. As in the present study, the production of flavonoids by $C$. cyanus organs was also reported by Litvinenko and Bubenchikova (2007). Both tannins and flavonoids are described as phenolic compounds; they have gastroprotective properties and an ability to inhibit oxidative processes and aid the control of gall bladder (Pirvu et al. 2012). Furthermore, flavonoids in plants are responsible for the colour and aroma of flowers and fruits, which is important for attracting pollinators and seed dispersal. These compounds protect plants against various biotic and abiotic stresses and act as a unique UV filter. In addition, they are used as signal molecules, allelopathic compounds, phytoalexins, detoxification agents and repellents of pathogenic microorganism and other pests and play a role in frost and drought resistance (Jurzitza 1987; Harborne 1988; Amalesh et al. 2011). In our study, the presence of terpenes containing steroids in the ducts was revealed with the use of antimony trichloride. Fernandez et al. (1995) found that loliolide was produced in $C$. cyanus organs. This terpene compound has many biological properties, e.g. antibacterial, anti-cancer, antifungal and antioxidant activity. Furthermore, plants containing loliolide are used in alternative medicine in the treatment of diabetes and depression (Grabarczyk et al. 2015). In other studies, this compound was present in other Asteraceae 
species such as Artemisia suksdorfii or Helianthus tuberosus (Ahmed et al. 2004; Pan et al. 2009). The histochemical assays of the $C$. cyanus secretory ducts did not reveal the presence of pectic-like substances. Similar observations were made in the research of reservoirs found in Matricaria chamomilla or Santolina ligustica (Pagni et al. 2003; Andreucci et al. 2008).

The ducts found in the C. cyanus organs were delimited by a single epithelial layer mostly consisting of five secretory cells. A comparison of the number of layers of epithelial cells between secretory structures in other species showed a strong resemblance to Tagetes patula, in which a uniseriate epithelium was detected as well (Poli et al. 1995). In the Asteraceae family, there are species having cavities with a biseriate epithelium (Conyza canadensis) (Lersten and Curtis 1987) or several layers of glandular cells (Tagetes minuta) (Simon et al. 2002).

In $C$. cyanus, numerous vesicles containing a heterogeneous secretory substance were detected in close vicinity of the epithelial cell walls. Similar structures were also described in epithelial cells of other Asteraceae representatives, e.g. Inula helenium (Sulborska 2007) and Rhaponticum carthamoides (Lotocka and Geszprych 2004). Myelin-like figures were visible in the secretory cells in the cytoplasm as well. They had the same appearance as those found in the Inula helenium nectary (Sulborska and WeryszkoChmielewska 2007). Elaioplasts, which stored fats, were found in the structure of the epithelial cells. This type of plastids was described in Grindelia pulchella (Asteraceae) glandular trichomes and ducts by Bartoli et al. (2011).

\section{Conclusions}

The aboveground organs of Centaurea cyanus exhibited four types of non-glandular trichomes, which may have taxonomic value and deter herbivores. Taxonomic relevance can also be ascribed to the papillae present on the petal lobes, the cuticular pattern observed on the petals of ray flowers as well as stylar and stamen hairs, and the prismatic deposits of calcium oxalate crystals in the bracts. Moreover, the presence of the hairlike structures on the C. cyanus flowers indicated their possible involvement in protection of nectar against dilution and/or drying out (trichomes on the surface of the stamens) and their role in secondary pollen presentation (trichomes and papillae on the pistil surface, which play an important role in flower pollination).

Two main secretory structure types, i.e. biseriate glandular trichomes and ducts, were found in the $C$. cyanus organs. The histochemical assays indicated the presence of various compounds such as essential oil, flavonoids, lipids, tannins and terpenes containing steroids and revealed a heterogeneous nature of the $C$. cyanus secretion produced by the ducts. The secretory ducts located in the stems were formed schizogenously. The epithelial cells of the same duct were in different stages of development. In the epithelial cells, and strongly osmiophilic insoluble phenolic material was stored in the vacuoles, whereas elaioplasts and vesicles contained, moderately osmiophilic insoluble lipidic material.

Funding information This study was supported by the Ministry of Science and Higher Education of Poland as part of the activities of the Department of Botany, University of Life Sciences in Lublin (project $\mathrm{OKB} / \mathrm{MN} / 3$ ).

\section{Compliance with ethical standards}

Conflict of interest The authors declare that they have no conflict of interest.

Open Access This article is distributed under the terms of the Creative Commons Attribution 4.0 International License (http:// creativecommons.org/licenses/by/4.0/), which permits unrestricted use, distribution, and reproduction in any medium, provided you give appropriate credit to the original author(s) and the source, provide a link to the Creative Commons license, and indicate if changes were made.

\section{References}

Afolayan AJ, Meyer JJM (1995) Morphology and ultrastructure of secreting and nonsecreting foliar trichomes of Helichrysum aureonitens (Asteraceae). Int J Plant Sci 156:481-487

Ahmed AA, El-Moghazy SA, El-Shanawany MA, Abdel-Ghani HF, Karchesy J, Sturtz G, ... \& Paré PW (2004) Polyol monoterpenes and sesquiterpene lactones from the Pacific Northwest plant Artemisia suksdorfii. J Nat Prod 67:1705-1710

Aktumsek A, Zengin G, Guler OG, Cakmak YS (2011) Screening for in vitro antioxidant properties and fatty acid profiles of five Centaurea L. species from Turkey flora. Food Chem Toxicol 49: 2914-2920

Amalesh S, Gouranga D, Sanjoy D (2011) Roles of flavonoids in plants. Int J Pharm Sci Technol 6:12-35

de Andrade WM, Loeuille BFP, Siniscalchi CM, Melo-de-Pinna GF, Pirani JR (2014) Diversity of non-glandular trichomes in subtribe Lychnophorinae (Asteraceae: Vernonieae) and taxonomic implications. Plant Syst Evol 300:1219-1233

Andreucci AC, Ciccarelli D, Desideri I, Pagni AM (2008) Glandular hairs and secretory ducts of Matricaria chamomilla (Asteraceae): morphology and histochemistry. Ann Bot Fenn 45:11-18

Angulo M, Dematteis M (2014) Cytotaxonomy of some species of the South American genus Lessingianthus (Asteraceae, Vernonieae). Plant Syst Evol 298:277-285

Ascensão L, da Silva JAT, Barroso JG, Figueiredo AC, Pedro LG (2001) Glandular trichomes and essential oils of Helichrysum stoechas. Isr J Plant Sci 49:115-122

Aschenbrenner AK, Horakh S, Spring O (2013) Linear glandular trichomes of Helianthus (Asteraceae): morphology, localization, metabolite activity and occurrence. AoB Plants 5:plt028

Baagøe J (1977) Taxonomical application of ligule microcharacters in Compositae I. Anthemideae, Heliantheae, and Tageteae. Bot Tidsskr 71:193-223

Baagøe J (1978) Taxonomical application of ligule microcharacters in Compositae I. Arctoideae, Astereae, Calenduleae, Eremothamneae, 
Inuleae, Labeae, Mutisieae, and Senecioneae. Bot Tidsskr 72:125146

Bartoli A, Galati BG, Tortosa RD (2011) Anatomical studies of the secretory structures: Glandular trichomes and ducts, in Grindelia pulchella Dunal (Astereae, Asteraceae). Flora 206:1063-1068

Bondarev NI, Sukhanova MA, Semenova GA, Goryaeva OV, Andreeva SE, Nosov AM (2010) Morphology and ultrastructure of trichomes of intact and in vitro plants of Stevia rebaudiana Bertoni with reference to biosynthesis and accumulation of steviol glycosides. Mosc Univ Biol Sci Bull 65:12-16

Boršic I, Sussana A, Bancheva S, Garcia-Jacas N (2011) Centaurea sect. Cyanus: nuclear phylogeny, biogeography, and life - form evolution. Int J Plant Sci 172:238-249

Brundrett MC, Kendrick B, Peterson CA (1991) Efficient lipid staining in plant material with Sudan Red 7B or Fluoral Yellow 088 in polyethylene glycol-glycerol. Biotech Histochem 66:111-116

Budel JM, Duarte MR, Döll-Boscardin PM, Farago PV, Matzenbacher NI, Sartoratto A, Sales Maia BHLN (2012) Composition of essential oils and secretory structures of Baccharis anomala, B. megapotamica and B. ochracea. J Essent Oil Res 24:19-24

Cappelletti EM, Caniato R, Appendino G (1986) Localization of the cytotoxic hydroperoxyeudesmanolides in Artemisia umbelliformis. Biochem Syst Ecol 14:183-190

Charrière-Ladreix Y (1976) Répartition intracellulaire du secrétat flavonique de Populus nigra L. Planta 129:167-174

Chiru T (2009) Phytochemical study of Centaurea cyanus. USAMV. Bucharest Ser A 52:293-297

Chiru T, Calalb T, Nistreanu A (2013) Morphological and anatomical studies of Cyani herba. Mod Phytomorphol 4:65-68

Ciccarelli D, Garbari F, Pagni AM (2007) Glandular hairs of the ovary: a helpful character for Asteroideae (Asteraceae) taxonomy? Ann Bot Fenn 44:1-7

Clark G (1981) Staining procedures, 4th edn. Williams and Wilkins, Baltimore

Cote GG, Gibernau M (2012) Distribution of calcium oxalate crystals in floral organs of Araceae in relation to pollination strategy. Am J Bot 99:1231-1242

Dane F, Meric C, Hüseyinova G (2000) Some ultrastructural observations on calcium oxalate raphide crystal idioblasts and meristematic cells of the adventive root tips of Sternbergia lutea (L.) Ker-Gawl. ex Sprengel (Amaryllidaceae). Turk J Bot 24:71-80

David R, Carde JP (1964) Coloration differéntielle des pseudophylles de Pin maritime au moyen du réactif de Nadi. C R Acad Sci Paris 258: $1338-1340$

Denisow B (2006) Blooming and pollen production of several representatives of the genus Centaurea L. J Apic Sci 50:13-20

Duke SO, Paul RN (1993) Development and fine structure of the glandular trichomes of Artemisia annua L. Int J Plant Sci 154:107-118

Erbar C, Leins P (2015) Cuticular patterns on stylar hairs in Asteraceae: a new micromorphological feature. In J Plant Sci 176:269-284

Fernandez I, Pedro JR, Polo E (1995) Sesquiterpene lactones from Centaurea alba and C. conifera. Phytochemistry 38:655-657

Franceschi VR, Nakata PA (2005) Calcium oxalate in plants: formation and function. Annu Rev Plant Biol 56:41-71

Fritz E, Saukel J (2011) Secretory structures of subterranean organs of some species of the Cardueae, and their diagnostic value. Acta Biol Cracov Ser Bot 53:63-73

Gabe M (1968) Techniques histologiques. Masson, Paris, France, p 204

Garbacki N, Gloguen V, Damas J (1999) Anti-inflammatory and immunological effects of Centaurea cyanus flower-heads. J Etnopharmacol 68:235-241

Göpfert JC, Bülow A-K, Spring O (2010) Identification and functional characterization of a new sunflower germacrene A synthase (HaGAS3). Nat Prod Commun 5:709-715

Grabarczyk M, Wińska K, Maczka W, Potaniec B, Anioł M (2015) Loliolide - the most ubiquitous lactone. Folia Biol Oecol 11:1-8
Hansen HV (1991) Phylogenetic studies in Compositeae tribe Mutisieae. Opera Bot 109:1-50

Haratym W, Weryszko-Chmielewska E (2012) The ecological features of flowers and inflorescences of two species of the genus Petasites Miller (Asteraceae). Acta Agrobot 65:37-46

Harborne JB (1988) The Flavonoids: Advances in Research since 1980. Chapman and Hall, London

Hayat MQ, Ashraf M, Khan MA, Yasmin G, Shaheen N, Jabeen S (2009) Diversity of foliar trichomes and their systematic implications in the genus Artemisia (Asteraceae). Int J Agric Biol 11:542-546

Heinrich G, Pfeifhofer HW, Stabentheiner E, Sawidis T (2002) Glandular hairs Sigesbeckia jorullensis Kunth (Asteraceae): morphology, histochemistry and composition of essential oil. Ann Bot 89:459-469

Hohmann B, Reher G, Stahl-Biskup E (2001) Mikroskopische Drogenmonographien der deutschsprachigen Arzneibücher: mit 7 Tabellen. Wiss. Verlangs-Gesellschaft, Stuttgard, p 9

Horner HT, Wanke S, Samain M-S (2009) Evolution and systematic value of leaf crystal macropatterns: a phylogenetic approach in the genus Peperomia (Piperaceae). Int J Plant Sci 170:343-354

Horner HT, Wanke S, Samain M-S (2012) A comparison of leaf crystal macropatterns in the two sister genera Piper and Peperomia (Piperaceae). Am J Bot 99:983-997

Huang SS, Kirchoff BK, Liao JP (2008) The capitate and peltate glandular trichomes in Lavandula pinnata L. (Lamiaceae): histochemistry, ultrastructure and secretion. J Torrey Bot Soc 135:155-167

Hulley IM, Viljoen AM, Tilney PM, Van Vuuren SF, Kamatou GPP, Van Wyk BE (2010) The ethnobotany, leaf anatomy, essential oil variation and biological activity of Pteronia incana (Asteraceae). S Afr J Bot 76:668-675

Jacobs B, Huysmans S, Smets E (2010) Evolution and systematic value of fruit and seed characters in Adoxaceae (Dipsacales). Taxon 59: $850-866$

Jensen WA (1962) Botanical histochemistry principles and practice, 1st edn. WH Freeman and Company, San Francisco, USA

Johansen DA (1940) Plant microtechnique, 1st edn. McGraw Hill, New York, London, USA, UK

Jurzitza G (1987) Anatomie der Samenpflanzen. Thieme Verlag, Stuttgart, $\mathrm{p} 55$

Karamenderes C, Konyalioglu S, Khan S, Khan IA (2007) Total phenolic contents, free radical scavenging activities and inhibitory effects on the activation of NF-kappa B of eight Centaurea L. species. Phytother Res 21:488-491

Karnovsky MJ (1965) A formaldehyde-glutaraldehyde fixative of high osmolarity for use electron microscopy. J Cell Biol 27:137 A

Kartal C (2016) Calcium oxalate crystals in some species of the tribe Cardueae (Asteraceae). Bot Sci 94:107-119

Kirk Junior PW (1970) Neutral red as a lipid fluorochrome. Stain Technol 45:1-4

Koch K, Bennemann M, Bohn HF, Albach DC, Barthlott W (2013) Surface microstructures of daisy florets (Asteraceae) and characterization of their anisotropic wetting. Bioinspir Biomim 8(3):036005

Kromer K, Kreitschitz A, Kleinteich T, Gorb SN, Szumny A (2016) Oil secretory system in vegetative organs of three Arnica taxa: essential oil synthesis, distribution and accumulation. Plant Cell Physiol 57: 1020-1037

Kuo-Huang L-L, MSB K, Franceschi VR (2007) Correlations between calcium oxalate crystals and photosynthetic activities in palisade cells of shade-adapted Peperomia glabella. Bot Stud 48:155-164

Küpeli Akkol E, Arif R, Ergun F, Yesilada E (2009) Sesquiterpene lactones with antinociceptive and antipyretic activity from two Centaurea species. J Ethnopharmacol 122:210-215

Leins P, Erbar C (2006) Secondary pollen presentation syndromes of the Asterales - a phylogenetic perspective. Botanische Jahrbücher 127:83-103 
Lersten NR, Curtis JD (1987) Internal secretory spaces in Asteraceae. A review and original observations on Conyza canadensis (tribe Astereae). La Cellule 74:181-196

Lison L (1960) Histochemie et cytochemie animals. Principes et méthods, vol 1, 2. Gauthier-Villars, Paris, France

Litvinenko VI, Bubenchikova VN (2007) Phytochemical study of Centaurea cyanus. Chem Nat Compd 24:672-674

Łotocka B, Geszprych A (2004) Anatomy of the vegetative organs and secretory structures of Rhaponticum carthamoides (Asteraceae). Bot J Linn Soc 144:207-233

Luković J, Malenčić D, Zorić L, Kodranov M, Karanović D, Kiprovski B, Boža P (2013) Anatomical characteristics and antioxidant ability of Centaurea sadleriana reveals an adaptation towards drought tolerance. Cent Eur J Biol 8:788-798

Mace ME, Bell AA, Stipanovic RD (1974) Histochemistry and isolation of gossypol and related terpenoids in roots of cotton seedlings. Phytopathology 64:1297-1302

Mcmanus JFA (1948) Histological and histochemical use of periodic acid. Stain Technol 23:99-108

Meric C (2009a) Calcium oxalate crystals in some species of the tribe Inuleae (Asteraceae). Acta Biol Cracov Ser Bot 51:105-110

Meric C (2009b) Calcium oxalate crystals in Aster squamatus and Bellis perennis (Asteraceae: Astereae). Phytol Balc 15:255-259

Metcalfe CR, Chalk L (1972) Anatomy of the Dicotyledons: leaves, stem, and wood in relation to taxonomy, with notes on economic uses. Clarendon Press, Oxford

Mirek Z, Piękoś-Mirkowa H, Zając A, Zając M (2002) Flowering plants and pteridophytes of Poland. A checklist. W Szafer Institute of Botany, Polish Academy of Science, Kraków

Muravéva DA, Bubenchikova VN (2007) Phenylcarboxylic acids of the flowers of Centaurea cyanus. Chem Nat Compd 22:102

Muravnik LE, Kostina OV, Shavarda AL (2016) Glandular trichomes of Tussilago farfara (Senecioneae, Asteraceae). Planta 244:737-752

Nwosu SI, Stanley HO, Okerentugba PO (2013) Occurrence, types and location of calcium oxalate crystals in Vernonia amygdalina Del. (Asteraceae). Int J Sci Nat 4:533-537

Pagni AM, Orlando R, Masini A, Ciccarelli D (2003) Secretory structures of Santolina ligustica Arrigoni (Asteraceae), an Italian endemic species. Isr J Plant Sci 51:185-192

Pan L, Sinden MR, Kennedy AH, Chai H, Watson LE, Graham TL, Kinghorn AD (2009) Bioactive constituents of Helianthus tuberosus (Jerusalem artichoke). Phytochem Lett 2:15-18

Pirvu L, Dragomir C, Schiopu S, Mihul C (2012) Vegetal extracts with gastroprotective activity. Part. I. Extracts obtained from Centaurea cyanus L. raw material. Rom Biotechnol Lett 17:7169-7176

Pirvu L, Bubuenau C, Panteli M, Petcu L, Coprean D (2015) Centaurea cyanus L. polysaccharides and polyphenols cooperation in achieving strong rat gastric ulcer protection. Open Chem 13:910-921

Plos A, Sancho G, Iharlegui L (2011) Secretory structures of leaves of Ophryosporus Meyen (Asteraceae, Eupatorieae), a genus with medicinal properties. J Torrey Bot Soc 138:391-399

Poli F, Sacchetti G, Bruni A (1995) Distribution of internal secretory structures in Tagetes patula (Asteraceae). Nord J Bot 15:197-205

Polish Pharmacopoeia VIII (2008) Polish Pharmaceutical Society, Warszawa

Prychid CJ, Rudall PJ (1999) Calcium oxalate crystals in monocotyledons: a review of their structure and systematics. Ann Bot 84:725739

Rahiminejad MR, Mozaffarian V, Montazerolghaem S (2010) A taxonomic revision of Centaurea section Acrocentron (Asteraceae) in Iran. Bot J Linn Soc 163:99-106

Rai M, Kon K (2013) Fighting multidrug resistance with herbal extracts, essential oils and their components. Academic Press, London, p 213
Reynolds ES (1963) The use of lead citrate at high $\mathrm{pH}$ as an electronopaque stain in electron microscopy. J Cell Biol 17:208-213

Rösch M (1998) The history of crops and crop weeds in southwestern Germany from the Neolithic period to modern times, as shown by archaebotanical evidence. Veg Hist Archaeobotany 7:109-125

Rzymowska Z, Skrzyczyńska J (2007) Niektóre cechy biologiczne Agrostemma githago L. i Centaurea cyanus L. w różnych siedliskach Wysoczyzny Siedleckiej/Selected biological features of Agrostemma githago L. and Centaurea cyanus L. at various habitats of the Siedlecka Upland/. Ann Univ Mariae Curie Sklodowska Sec E 62:82-89

Senderski ME (2007) Prawie wszystko o ziołach [Almost everything about herbs]. Senderski ME (ed), Podkowa Leśna, pp 603-605

da Silva EMS, Hische Hayashi A, Appezzato-da-Glória B (2014) Anatomy of vegetative organs in Aldama tenuifolia and A. kunthiana (Asteraceae: Heliantheae). Braz J Bot 37:505-517

Silva MP, Tourn GM, López D, Galati BG, Piazza LA, Zarlavsky G, Cantero JJ, Scopel AL (2015) Secretory structures in Flourensia campestris and F. oolepis ultrastructure, distribution, and (-)hamanasic acid a secretion. Am J Plant Sci 6:925-942

Simon PM, Katinas L, Arambarri M (2002) Secretory tissues in Tagetes minuta (Asteraceae, Helenieae). Boletin SAB 37:181-191

Stanojković A, Ceković G, Čomić L, Pivić R, Stanojković A (2008) Antibacterial properties of some plants from the family Asteraceae growing wild in Serbia. Lek Sirov 26(27):11-20

Sulborska A (2007) Distribution and structure of internal secretory reservoirs on the vegetative organs of Inula helenium L. (Asteraceae). Acta Agrobot 60:1-12

Sulborska A (2011) Micromorphology of flowers, anatomy and ultrastructure of Chamomilla recutita (L.) Rausch. (Asteraceae) nectary. Acta Agrobot 64:23-34

Sulborska A (2013) Structure and distribution of glandular and nonglandular trichomes on above-ground organs in Inula helenium L. (Asteraceae). Acta Agrobot 66:25-34

Sulborska A, Weryszko-Chmielewska E (2007) Anatomy and ultrastructure of floral nectar of Inula helenium L. (Asteraceae). Acta Soc Bot Pol 76:201-207

Susanna A, Garcia-Jacas N (2009) Cardueae (Carduoideae). In: Funk VA, Susanna A, Stuessy TF, Bayer RJ (eds) Systematics evolution, and biogeography of Compositae. International Association for Plant Taxonomy, Vienna, Austria, pp 293-313

Tooulakou G, Giannopoulos A, Nikolopoulos D, Bresta P, Dotsika E, Orkoula MG, ... \& Karabourniotis G (2016) Alarm photosynthesis: calcium oxalate crystals as an internal $\mathrm{CO} 2$ source in plants. Plant Physiol 171:2577-2585

Wagenitz G, Hellwig FH (1996) Evolution of characters and phylogeny of the Centaureinae. In: Hind DJN, Beentje HG (eds) Compositae: systematics. Proceedings of the international Compositae conference. Royal Botanic Gardens, Kew, pp 491-510

Wassmuth BE, Stoll P, Tscharntke T, Thies C (2009) Spatial aggregation facilities coexistence and diversity of wild plant species in field margins. Perspect Plant Ecol Evol Syst 11:127-135

Werker E, Putievsky E, Ravid U, Dudai N, Katzir I (1994) Glandular hairs, secretory cavities, and the essential oil in the leaves of tarragon (Artemisia dracunculus L.). J Herbs Spices Med Plants 2:19-32

Williams BC (1954) Observations on intercellular canals in root tips with special reference to the Compositeae. Ann J Bot 41:104-106

Publisher's note Springer Nature remains neutral with regard to jurisdictional claims in published maps and institutional affiliations. 